\title{
Grasping darkness: the dark ecological network as a social-ecological framework to limit the impacts of light pollution on biodiversity
}

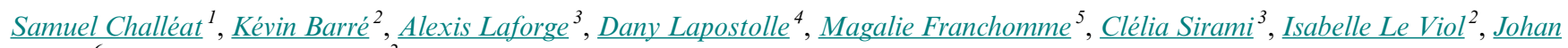
$\underline{\text { Milian }}^{6}$ and Christian Kerbiriou ${ }^{2}$

\begin{abstract}
Artificial light at night (ALAN) is nowadays recognized as a major anthropogenic pressure on the environment on a global scale and as such is called light pollution. Through its attractive or deterrent effects, and its disruption of the biological clock for many animal and plant taxa, ALAN is increasingly recognized as a major threat to global biodiversity, which ultimately alters the amount, the quality, and the connectivity of available habitats for taxa. Biodiversity conservation tools should, therefore, include ALAN spatial and temporal effects. The ecological network, i.e., the physical and functional combination of natural elements that promote habitat connectivity, provides a valuable framework for that purpose. Understood as a social-ecological framework, it offers the opportunity to take into account the multiple uses of nocturnal spaces and times, by humans and nonhumans alike. Here we present the concept of "dark ecological network." We show this concept is able to grasp the effects of ALAN in terms of habitat disturbances and integrates temporal dimensions of ecological processes into biodiversity conservation planning. Moreover, it is also intended to trivialize the practices of darkness protection by turning them into the ordinary practices of land use planning. From an operational point of view, the challenge is to translate the levers for reducing ALAN-induced effects into a political method for its "territorialization." To achieve this objective, we propose a course of action that consists of building an interdisciplinary repertoire of contextualized knowledge (e.g., impacts on wildlife, human/lightscape relationship, existing legal tools, etc.), in order to deduce from it a number of practical supports for the governance of the dark ecological network in response to societal and ecological issues.
\end{abstract}

Key Words: artificial light at night (ALAN); darkness; ecological network; land-use planning; light pollution; multilevel approach; participatory processes; social-ecological systems

\section{INTRODUCTION}

Habitat destruction, reduction, transformation, and/or isolation profoundly affect the dynamics of populations, communities, and ecosystems, as well as underlying ecological processes and in turn biodiversity levels (Soulé and Orians 2001). Based on this observation, many studies have highlighted the need to move from the conservation of only a few remarkable habitats and species to the conservation of more ordinary ones (Margules and Pressey 2000, Hansen and De Fries 2007, Thompson et al. 2011). Moreover, to promote ecologically functional habitats, ecological planning must focus on appropriate spatial scales to account for habitat connectivity (Fischer and Lindenmayer 2007). The concept of ecological network has emerged in response to this need for renewed conservation policies and spatial design (Opdam et al. 2006, Boitani et al. 2007). It is intended to grasp the ecological conditions necessary for individuals and populations to maintain in a fragmented habitat, for example, by maintaining a sufficient diversity, size, shape, and connection of favorable habitat patches according to considered species or communities. The strength of this concept, developed on the basis of island biogeography theories (MacArthur and Wilson 1967) and population dynamics (Levins 1969), allows for "a shift away from the "topologic" approach to conservation, involving only protected areas, and to the landscape "chorological" approach, involving the whole territory" (Battisti 2003:241).
It is therefore essential to approach ecological networks from a twofold pragmatic perspective and within the framework of integrated conservation (McShane and Wells 2004): to combat landscape homogenization and habitat fragmentation on the one hand (Jongman 2002), and to integrate conservation theories into landscape and land use planning practices on the other (Opdam et al. 2006). On this last point, Battisti (2003:241) insists that "this planning must take into account the "real world", whose interpretation needs a multidisciplinary approach (Haila 1985, Soule 1986): applied ecologists and wildlife managers will have to interact with landscape planners and politicians, although their languages are different." In this perspective, the concept of "ecological network" has established itself in the field of nature conservation (Bischoff and Jongman 1993).

There are debates on the effectiveness of ecological networks within the scientific community (on that issue we can compare the words of Boitani et al. 2007 or Lévêque 2017 with what Rientjes and Roumelioti 2003 or Samways and Pryke 2016 for instance, had to say about that). Yet, the concept has nevertheless achieved unprecedented social and political success (Jongman 1995), particularly in Europe, in a landscape context under heavy human domination (Vimal et al. 2012). The introduction of this scientific concept into the political arena has resulted in the PanEuropean Biological and Landscape Diversity Strategy. It was

${ }^{1}$ UMR 5602 GÉODE (Géographie de l'environnement), Centre national de la recherche scientifique, Université Toulouse - Jean Jaurès, ${ }^{2}$ UMR 7204 CESCO (Centre d'écologie et des sciences de la conservation), Muséum national d'Histoire naturelle, Centre national de la recherche scientifique, Sorbonne Université. Station marine Concarneau, ${ }^{3}$ UMR 1201 DYNAFOR (Dynamiques et écologie des paysages agriforestiers), Université de Toulouse, Institut national de recherche pour l'agriculture, l'alimentation et l'environnement, ${ }^{4}$ UMR 6049 ThéMA (Théoriser et modéliser pour aménager), Centre national de la recherche scientifique, Université Bourgogne-Franche-Comté, ${ }^{5}$ ULR 4477 TVES (Territoires, villes, environnement \& société), Université de Lille, Université Littoral Côte d'Opale, ${ }^{6}$ UMR 7533 LADYSS (Laboratoire dynamiques sociales et recomposition des espaces), Centre national de la recherche scientifique, Université Paris 8 Vincennes - Saint-Denis 
initiated in 1995 by the European Ministers of the Environment in association with the United Nations and the Council of Europe (Jongman et al. 2004). This strategy's primary objective was to create a Pan-European ecological network (Jongman and Pungetti 2004, Jongman et al. 2011): a homogeneous and coherent network from a geographical and ecological point of view, consisting of core areas, corridors, restoration areas, and buffer zones. Since the late 1990s, many European Union (EU) member states have implemented a national ecological network planning policy (Bennett and Wit 2001, Jongman and Kristiansen 2001). The EU is now seeking to harmonize these national policies. It is working on the establishment of a green infrastructure (GI), defined as "a strategically planned network of natural and seminatural areas with other environmental features designed and managed to deliver a wide range of ecosystem services. It incorporates green spaces (or blue where aquatic ecosystems are concerned) and other physical features in terrestrial (including coastal) and marine areas. On land, GI is present in rural and urban settings" (European Commission 2013:3). Member states currently trying to implement such networks have to compromise between scientific knowledge on the one hand and local political and social issues on the other (Alphandéry et al. 2012).

Current approaches to building ecological networks do not explicitly integrate ecosystems' temporal dynamics: they are only based on a daytime perception and on material causes of habitat fragmentation. However, although their planning claims to take into account the "real world" (Battisti 2003), ecological networks should also consider the nocturnal dimension of ecosystems. Indeed, in this "real world", when it comes to repelling the daily descent of darkness, societies deploy specific techniques, such as artificial light at night (ALAN) and more particularly outdoor spaces lighting (Brox 2010). ALAN is a space planning tool that responds to multiple social uses, e.g., security enhancement of goods and people, nighttime economy activities, architectural aestheticism, city marketing and promotion. However, the degradation of the darkness generated in and around urban areas is nowadays understood as a source of pollution in its own right, so-called "light pollution" (Riegel 1973). Street light sources or other public light sources are of course not the only ones responsible for light pollution; it has recently been shown that many other privately operated sources, e.g., illuminated signs, can play a non-negligible role in the emission of artificial light from urban areas (Kyba et al. 2020). ALAN negative effects are therefore at the heart of the complex interactions that occur between the environment and societies within anthropized nocturnal space-time.

Several recent studies have pointed out that environmental protection tools do not include the issues raised by ALAN-related impacts (Schroer et al. 2020). For example, this major anthropic pressure is not taken into account in the network of Natura 2000 sites, the European policy flagship tool for the preservation of biodiversity. As a consequence, conservation planning tools urgently need to account for ALAN effects on habitat loss and fragmentation, namely examples from highly mobile taxa such as bats (Laforge et al. 2019, Pauwels et al. 2019). Hence, it is essential to retain and develop "dark ecological networks." Global ecological networks would benefit from specific dark ecological networks because they share specific features. First, ecological corridors such as wooded edges and rivers (classically part of global ecological networks) are also often constrained by ALAN (Spoelstra et al. 2017, Barré et al. 2020), hence highly important in lighting reduction schemes. Second, a great number of ecological communities composing global ecosystems, i.e., nocturnal and diurnal, are expected to be influenced by ALAN because $28 \%$ of vertebrates and $64 \%$ of invertebrates are nocturnal worldwide (Hölker et al. 2010). Then, ALAN affects parts of trophic chains not limited to night and affects other neighbor ecosystems (Manfrin et al. 2017). However, it is also necessary to articulate to what degree ALAN affects ecological processes and the scales of ALAN management by institutions. This articulation represents a challenge traditionally encountered in the treatment of environmental problems (Cumming et al. 2006). This challenge is made worse concerning ALAN because of the diffuse nature of light pollution, the plurality of its effects, as well as the uncertainties that remain about its effects at various geographical/temporal scales and/or ecological levels. This results in a current mismatch between scales of knowledge and scopes of action.

The purpose of this article is twofold. Based on the conceptual framework of ecological networks, the first objective is to present the concept of dark ecological network and to clarify its aims, particularly from ecological and geographical points of view. The second objective is to highlight the challenges involved in translating the dark ecological network as a concept defined by scientists - both in its theoretical and practical dimensions, for example when discussing and defining its shape, structure, or components (Boitani et al. 2007) -into an action-oriented tool. To meet these two objectives, we highlight the global dimension of the various problems caused by light pollution. We show the intertwining of the spatial and temporal dimensions of ALAN ecological effects. We also define the scientific concept of dark ecological network. We emphasize the intrinsically socioecosystemic dimension of this concept. That concept dimension makes it possible to grasp the multiple facets of darkness preservation as a resource in its own right. More particularly, we show that this concept permits us to envision a junction between practices that have until now been implemented in a disjointed way - the development of protection and enhancement areas of the starry sky on a large scale, and the spatiotemporal management of lighting on a fine scale. Finally, we outline some of the issues raised by the translation of the dark ecological network as a scientific concept into the dark ecological network, understood as an action-oriented tool. In other words, we are discussing the transition from a scientific method to an unavoidable political compromise for the "territorialization" of darkness protection.

\section{LIGHT POLLUTION, A GLOBAL ENVIRONMENTAL PROBLEM}

Tightly linked to urbanization, outdoor lighting has grown by between $3 \%$ and $6 \%$ per year during the second half of the 20th century (Hölker et al. 2010). Even today, ALAN is increasing in most parts of the world. Between 2012 and 2016, Earth's artificially lit outdoor surface area increased by $2.2 \%$ per year, with a radiance growth of $1.8 \%$ per year. As for the brightness of continuously illuminated areas, it has increased by $2.2 \%$ per year (Kyba et al. 2017). De facto, light pollution affects $23 \%$ of the global land surface, including $88 \%$ of the European surface area (Falchi et al. 2016). Under the influence of aerosols suspended in 
the atmosphere, ALAN spills beyond urbanized areas over to protected surroundings and biodiversity hotspots (Guetté et al. 2018). Moreover, ALAN represents a significant part of global energy consumption, with $20 \%$ of global electricity consumption and, on the same scale, $6 \%$ of $\mathrm{CO}_{2}$ emissions (UNEP 2012), and about $3 \%$ of global oil demand (UNEP 2017). In the United States of America alone, International Dark-Sky Association estimates that at least $30 \%$ of all outdoor lighting is wasted. Still according to this NGO, this waste costs up to US\$3.3 billion a year and emits 21 million tons of carbon dioxide over the same period (see https://www.darksky.org/light-pollution/energy-waste/). This growing anthropogenic pressure contributes to global environmental changes through multiple mechanisms related to health, culture, and ecology.

\section{The health implications of ALAN}

From a health point of view, the natural alternation between light and darkness is the most powerful exogenous synchronizer of the master clock of peripheral clocks. This central clock controls all circadian biological rhythms, both for humans and wildlife (Gaston et al. 2017). The degradation of darkness by ALAN disrupts the synchronization of the central circadian clock, modifies sleep architecture, and inhibits melatonin secretion. These responses depend on several interacting factors: intensity (Cajochen et al. 2000, Zeitzer et al. 2005), duration (Chang et al. 2012), timing (Khalsa et al. 2003), temporal patterns (Rimmer et al. 2000, Gronfier et al. 2004, Najjar and Zeitzer 2016), and the spectral composition (Brainard et al. 2001, Thapan et al. 2001, Najjar et al. 2014) of the light stimulus. For instance, it has recently been shown that ALAN intensities between 2 and 10 photopic lux are sufficient to inhibit melatonin secretion and to disrupt the circadian clock in humans (Prayag et al. 2019). These intensities are far lower than those we are exposed to on a daily basis, via multiple domestic lighting systems, and are comparable to those generated by "intrusive light" (Falchi 2018) in a bedroom without shutters in an urban context.

\section{The socio-cultural implications of ALAN}

In socio-cultural terms, the loss of natural darkness deteriorates several scientific (Riegel 1973) and cultural amenities (Gallaway 2010, Stone 2017, Challéat and Poméon 2020). ALAN “closes the window" on the starry sky (Isobe and Hirayama 1998) —one-third of humanity can no longer make out the Milky Way (Falchi et al. 2016). ALAN erodes darkness and reduces the relationship to this inexhaustible historical, literary, philosophical, religious landscape or artistic resource, which participates in our individuation, in the constitution of our being, and in our relationship with other humans and nonhumans (Galinier 2010, Le Gallic and Pritchard 2019, Lam 2020). ALAN thus contributes to the extinction of the experience of nature (Pyle 1978, Miller 2005, Soga and Gaston 2016) and fuels generational environmental amnesia (Kahn 2002). In addition, cultural geography studies emphasize the extent to which darkness makes possible original forms of conviviality and intimacy, the occupation of public spaces, and the perception of the world through senses other than sight (Edensor 2013, 2015, Shaw 2018). In other words, whatever the types of space involved, darkness preservation provides access to an array of experiences for the sensorial apprehension of the world.

\section{The ecological implications of ALAN}

Finally, ALAN produces many ecological disturbances (Rich and Longcore 2006, Sanders et al. 2021) and constitutes one of the least understood sources of perturbation affecting biodiversity (Gaston et al. 2015). Altering natural light and dark patterns in ecosystems, especially day/night rhythm (Gaston et al. 2017), ALAN impacts a wide range of taxa from the molecules level to ecosystems, interactions between species, and regulatory processes (Hölker et al. 2010, Gaston et al. 2017, Grubisic et al. 2017, Knop et al. 2017, Bennie et al. 2018a). ALAN plays a major part in the activity and energy metabolism of taxa by altering energy expenditure (e.g., Welbers et al. 2017, Touzot et al. 2020). Such a physiological consequence of ALAN may have a longterm negative effect on individuals' fitness across populations (Touzot et al. 2020). ALAN also fragments habitats, altering the functional connectivity of landscape for many species (Laforge et al. 2019). Indeed their avoidance-attractiveness mechanisms at more local scales (Barré et al. 2020) greatly depend on the species sensitivity according to their traits, e.g., fast-flying vs. slow-flying species, and light parameters, e.g., intensity and spectrum (Spoelstra et al. 2017, Azam et al. 2018). Such fragmentation due to ALAN has genetic implications that have recently been argued as a driver of evolution contributing to population differentiation across urban-rural landscapes (Hopkins et al. 2018). Species response to ALAN heavily depends on spatial scale, with, for example, positive effects on some bat species activity within the range of the surrounding streetlight (Azam et al. 2018), while with seriously negative effects at the national scale (Azam et al. 2016; Fig. 1). These authors have even shown that, for these taxa, ALAN poses a threat equivalent to others such as soil artificialization and the proportion of intensive agriculture on a large scale (Azam et al. 2016). Such spatial and temporal perturbation of habitats and species is suspected in turn to profoundly affect the functioning dynamics of populations, communities, and ecosystems (Falcón et al. 2020).

\section{THE INTERTWINED SPATIAL AND TEMPORAL DIMENSIONS OF ALAN ECOLOGICAL EFFECTS}

\section{The spatiotemporal dimensions of ALAN effects}

Habitat fragmentation constitutes a central concern about ALAN effects on biodiversity. The first purpose of the dark ecological network is to identify solutions to mitigate impacts. ALAN results in habitat fragmentation through two main mechanisms. The first one is the spatial barrier effect, which can be produced by individuals' physical or temporal isolation. Specifically, ALAN can generate illuminated areas that are more difficult for individuals to pass through than unlit areas, e.g., for bats (Lewanzik and Voigt 2014, Hale et al. 2015, Barré et al. 2020) and toads (van Grunsven et al. 2017). It induces direct spatial barriers for moving and results in habitat losses. ALAN also generates indirect spatial barrier effects because of temporal asynchronies inducing mismatches between lit and unlit areas, e.g., in the timing of grass species flowering later under artificial light (Bennie et al. $2018 b$ ) and producing less fruit (Knop et al. 2017). Indeed, such temporal asynchronies can induce a spatial differentiation between populations driven by the spatial distribution of artificial light (Altermatt and Ebert 2016), and ultimately a spatial barrier through evolutionary changes in populations (Hopkins et al. 2018). Such spatial or temporal isolation of populations could 
Fig. 1. Synthesis diagram pointing out the multilevel effects of ALAN and the challenges of articulating organizational levels for a bottom-up approach of the dark ecological network.

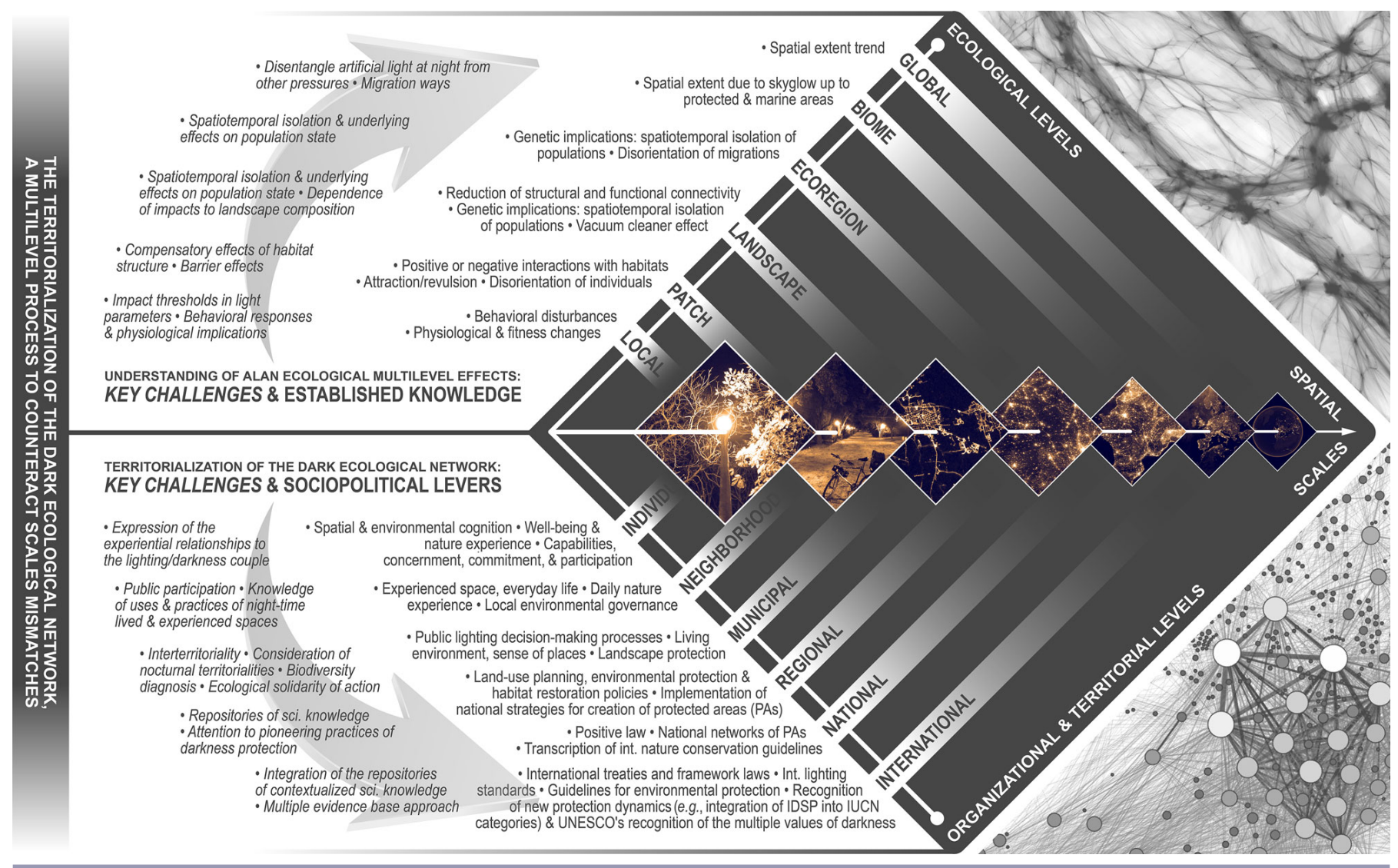

even ultimately limit gene flow and increase genetic drift as advocated by Hopkins et al. (2018). The second main mechanism through which ALAN causes habitat fragmentation is through its attractiveness to taxa. Indeed, light sources promote the accumulation of individuals of many species, such as arthropods in lit areas (Rydell 1992) and their depletion in unlit areas (Eisenbeis 2006). Artificial light also attracts predators such as insectivorous bats (Stone et al. 2015) or seabirds (Rodríguez et al. 2017) and could cause top-down and bottom-up trophic effects, as demonstrated, e.g., on invertebrate populations (Bennie et al. 2018a). ALAN also disrupts migration, alters fly paths, migration activity (Van Doren et al. 2017), and migratory stopover selection by birds (McLaren et al. 2018). Such attractive effects can thus generate modifications in the spatial use of habitats and ultimately compromise the life cycle achievement of species, e.g., access to reproduction sites or mates.

\section{Temporally fixed and local scale solutions used so far to reduce effects}

Much scientific knowledge is available and has already been used to reduce the impacts of ALAN. For instance, lights that contain the most blue and UV wavelengths, i.e., high and low-pressure mercury, metal-halide, and white light-emitting diodes, attract a higher number of arthropod species than other lights, i.e., low and high-pressure sodium, discharge lamps and amber LED (van Langevelde et al. 2011). However, although high-pressure sodium lights attract much fewer arthropods than lights containing more blue and UV wavelengths, they remain 27 times more attractive than dark conditions (Perkin et al. 2014). Taxa responses to light, regardless of whether they are positive or negative, are also known to be spectrum-dependent such as in birds (de Jong et al. 2015), reptiles (Witherington et al. 1991), toads (van Grunsven et al. 2017), or mice (Bird et al. 2004). It was also shown that red spectrum lights were equivalent to dark conditions for global activity of insectivorous bats (Spoelstra et al. 2017). Besides, although light from high-pressure sodium lamps or red LEDs, for example, attract fewer insects, it still has negative impacts on bat commuting (Stone et al. 2009, Zeale et al. 2018). However, it should be noted that spectrum-related effects remain highly diverse, either in bats (Voigt et al. 2018), in insects (van Grunsven et al.2019), and more generally in flora and fauna (Schroer and Hölker 2017).

\section{Toward solutions to reduce ALAN effects at different spatiotemporal scales}

However, such measures that aim at modifying streetlight attributes remain focused on the local scale and, although useful, they are most often not sufficient. Indeed, it has been shown that light pollution can remain a concern for natural ecosystems far away from city centers owing to light halo phenomena, which can be exacerbated in periods of cloudy nights (Secondi et al. 2017). Furthermore, following the example of bats and despite some positive effects at local scale for some species, ALAN shows a severe 
negative effect at larger spatial scales for all European guilds (Azam et al. 2016). Maintaining and increasing unlit areas likely remains the most efficient solution: reducing the trespass of lighting could keep habitat heterogeneity, which provides dark refuges. In the same way, decreasing lighting intensity limits skyglow and impacted areas (Gaston et al 2012). Some studies, however, found that current lighting schemes using switch-off strategies were not a promising solution for bats because they do not match with peaks of activity (Azam et al. 2015). More drastic options, i.e., using lamps that switch off between 00:00 and 04:00 am, were not fully effective, though they do reduce the number of taxa impacted for grassland invertebrate assemblages (Gaston et al. 2017). At conurbation scale, Laforge et al. (2019) tested different light-reduction scenarios and found that their efficiency to improve landscape connectivity for bats depends more on the type of land use, i.e., habitat, where light reduction is applied than on the total area impacted by it.

These results confirm that both ALAN effects on biodiversity and the efficiency of mitigation measures (such as light reduction/ extinction) depend on the spatial context. For instance, it was recently shown that the probability for greater horseshoe bats of crossing a gap in an ecological corridor, e.g., a hedgerow, substantially decreased from 38 meters (Pinaud et al. 2018), which constitutes key knowledge to mix with lighting schemes. In addition, it has been recently demonstrated that bats avoid streetlight at up to 50 meters (Azam et al. 2018). Coupled with knowledge about landscape connectivity such as Pinaud et al. (2018), it could help the implementation of an efficient dark ecological network. These results suggest that existing ecological networks could integrate such information as a framework to develop dark ecological ones.

The literature also suggests that ALAN effects on biodiversity depend on the temporal context. First, as explained in the introduction, species depend on regular day and night alternation that shapes their daily biological cycle. Perturbations of daily light cycles impact biological events such as singing for birds, daily movements, foraging, sleep, and recovery, documented about a wide range of taxa (Gaston et al. 2017). Then, at the peak of species abundance, foraging activity and breeding periods strongly depend on seasons (e.g., Newson et al. 2015, Salvarina et al. 2018, Lučan and Radil 2010). That is why species are affected differently by artificial lighting, according to time of year, e.g., response of avian daily rhythms to light intensity (de Jong et al. 2016). Monthly and seasonal regimes of lunar sky brightness also shape biological timings and spatial repartition of species, e.g., for zooplankton's vertical migrations, and can be masked or even very negatively impacted by the skyglow generated by the extent of artificial lighting sources (Davies et al. 2013, Ludvigsen et al. 2018). Finally, ALAN can generate long-term impacts. Indeed, ALAN can change community assemblages including diurnal ones, e.g., for invertebrates (Davies et al. 2012, 2017). ALAN can even have genetic impacts, as shown for a moth species in which individuals in lit areas had reduced flight-to-light behavior compared to those in unlit areas (Altermatt and Ebert 2016). Concerning solutions to mitigate such impacts, no studies, to our knowledge, have tested the efficiency of lighting schemes focused on long-term and seasonal impacts. However, accurately including long-term temporal processes in decision making to establish dark ecological networks appears essential to ensure the coexistence of humans and biodiversity in an increasingly urbanizing world (Secondi et al. 2017).

\section{THE DARK ECOLOGICAL NETWORK, A CONCEPT FOR MATCHING SCALES AND LEVELS OF DARKNESS PRESERVATION}

\section{On a large scale, the starry sky as the main horizon for an anthropocentric utilitarian protection of darkness}

At the international level, the fight against light pollution is carried out in different ways and supported by different actors. In its most advanced territorial form today, it can be seen in the protection of the starry sky through new zoning. It is built on a classic center-periphery logic: a high protection core area is surrounded by a buffer zone, but no environmental protection is expected outside. This logic, which has historically prevailed in the planning of many national and nature parks (Shafer 1999a, $b$, Dudley 2008), is the one currently used to implement "dark sky places" around the world (Charlier and Bourgeois 2013, Bénos et al. 2016).

Initiated in 1993 in the United States with the creation of the Dark Sky Preserve at Lake Hudson (Michigan), this territorial dynamic of starry sky protection really took off at the end of the 2000s. It is based on a labeled zoning logic, supported by various associations from the dark sky movement (Challéat and Lapostolle 2014, Challéat 2019). The International Dark-Sky Association is top of the list. Just over 140 territories are currently labeled by the latter. Its International Dark Sky Places (IDSP) status initially made it possible to distinguish high places of astronomical observation, and is now sought by conventional protected areas (according to the International Union for Conservation of Nature typology), hence extending to the starry sky the scope of their protection measures (Collison and Poe 2013). The main labeling criterion here is the existence of a remarkable starry sky. It can be easily mobilized in different valorization strategies (Rodrigues et al. 2015, Challéat and Poméon 2020). For example, the development of dark sky tourism and other territorial marketing strategies can lead to a purely utilitarian understanding of the starry sky as a new assessable economic good (Mitchell and Gallaway 2019). In this logic, the aesthetic or utilitarian criterions and considerations often muddle the ecological and health stakes of preserving darkness as a resource (Blundell et al. 2020, Lapostolle and Challéat 2021). Acting this way, in a field that should be a new front in the construction of conservation policies, proves to be a methodological step backwards with regard to the convergence efforts made since the 1990s in the field of conservation and the creation/evolution of protected areas. However, the articulation between territorial development issues and environmental protection matters is subject to local compromises. Guidelines are currently shifting thanks to their effects.

On a fine scale, "getting lighting right" using knowledge of spaces' nocturnal characteristics as a slow paradigm shift

The geographical concept of "nocturnal territoriality" (Raffestin 1988, Lapostolle and Challéat 2021) underscores the role of nighttime darkness in the change in our daily relations with the places we experience. Knowing nocturnal territorialities implies grasping in a situated way the daily practices and uses in and of the nighttime (Challéat and Lapostolle 2018). Taking into 
account the many different uses and approximations of nocturnal characteristics means partially moving away from technocratic prescriptions of what spaces should be (how a priori it should be planned), by giving back a role to do-it-yourself approaches with a view to adding other knowledge and experiences, i.e., other than those of experts, into the mix. This is essentially a form of landuse planning democratization. In addition to defining space in terms of the production of figures and procedural standards, it takes into account actual uses and experiences of spaces as two elements that contribute to shaping the sense of places (Chapin and Knapp 2015, Hausmann et al. 2016). Knowledge of nocturnal territorialities enables us to move toward the "right way of lighting" (éclairer juste), a set of practices condensed into a new urban lighting doctrine that seeks a settlement between our needs for artificial light and the set of ecological, health-based, and socio-cultural needs for darkness (Challéat 2019, Lapostolle and Challéat 2021). In France, for example, these new practices are brought together within the éclairer juste doctrine, which includes integrating environmental constraints into the economic logic of many lighting professionals. This doctrine is promoted on a national level by various dominant stakeholders in the lighting and energy sectors, like the Agence de l'environnement et de la maîtrise de l'énergie (ADEME), the Association française de l'éclairage, and the Syndicat de l'éclairage, a national syndicate that brings together national and international manufacturers of lamps, luminaires, candelabras, and electronic components used in the lighting industry (ADEME et al. 2010).

From the public lighting policies point of view, it is important to note that considering nocturnal territorialities is not in itself a fight against light pollution, but rather a fight against unnecessary expenditure, i.e., financial and energy savings (Franchomme et al. 2019). However, the "right way of lighting" doctrine is proving to be a frame of reference for action permeable to new environmental considerations. In other words, if considering nocturnal territorialities does not necessarily mean placing the fight against light pollution at the foundation and heart of the renewal of lighting practices, it nevertheless opens the way for integrating this issue into the production of tomorrow's urban lighting. It is in this frame of reference that the new public lighting regulation practices take place. For instance, in France, in the early 2010s, local-authority budget cuts and pressure to meet energytransition targets placed new constraints on urban lighting. As a result, an increasing number of municipalities, most often in rural areas, but also, increasingly, in (peri-)urban areas, have reduced or switched off public lighting at certain times of the day and/or certain periods in the year. But these actions remain spatially scattered, and politically uncoordinated: there is no interterritoriality for their implementation or, in other words, no articulation between the different organizational levels of action.

\section{The dark ecological network, a concept to strengthen the protection of darkness}

No reticular thinking presides over the implementation of IDSPtype zoning on the one hand, and of "right lighting" policies on the other. Although they are locally efficient to reduce light pollution and to increase awareness and concern about the multiple issues related to the preservation of darkness (Silver and Hickey 2020, Lapostolle and Challéat 2021), these initiatives and practices too often remain disjointed and are not networked. Moving from mere starry sky protection and/or from plain energy costs reduction to the preservation of all the benefits of darkness requires mobilizing a holistic protection tool such as the ecological network. In what is thus becoming a dark ecological network, IDSPs are "macro-reservoirs of darkness," i.e., core areas of darkness among others, linked by the other structural components of the network: dark landscape corridors, dark linear corridors, dark buffer zones, and dark stop-over sites (Fig. 2). In addition, the multiscale structure of the dark ecological network enables it to protect the darkness needed for ecological processes by capturing the multiple effects of ALAN on various scales, from the light footprint generated by a sole luminaire to the one generated by (mega)cities' skyglow.

Unlike IDSP-type zoning, the network has no center, no periphery, no clear boundary between inside and outside, but relies on its components' connectedness and connectivity. This structural characteristic provides it with lability, a property that is particularly effective in terms of preserving darkness. The habitat fragmentation caused by ALAN differs from the physical obstacles of linear transport infrastructure: the obstacle can be temporarily removed by switching off the lights. In addition, and contrary to issues encountered in agricultural environments, for example, where land and property rights matters require the mobilization of a complex set of actors, technical intervention on interconnected public lighting systems only involves a relatively small number of operators. These two specificities related to technical lighting systems make it possible to temporarily activate some elements of the dark ecological network according to seasonal ecological issues, first and foremost the dark (landscape) corridors and the dark stop-over sites. Here, following radically different spatial scales, we can start with the migratory passage or maiden flight of birds particularly ALAN sensitive (Horton et al. 2019), or the spring pollination in areas where the local economy is heavily dependent on fruit growing. Given this network's lability, isolated and scattered actions that already exist could be linked to the dark ecological network, such as Houston Audubon Lights Out Action Alerts in the USA (see: https:// houstonaudubon.org/conservation/bird-friendly-communities/lightsout.html), or Les nuits sans lumière (Nights without light, renamed Les jours de la nuit, Days of night) in the Réunion Island (see: https://www.lesjoursdelanuit.re). These operations consist in generating alerts or asking individuals, businesses, and communities to turn off the lights, during the passage of migratory birds in the USA, or during the ocean-ward maiden flight of the young Barau's Petrels (Pterodroma baraui) in the Réunion Island.

For and through the implementation of the dark ecological network, it is, therefore, a matter of deepening and extending darkness protection. Faced with the urgent need to preserve biodiversity, the dark ecological network enriches the tools for territorial action in the fight against light pollution. In other words, it is no longer just a question of protecting the starry sky or a few remarkable species, but of protecting the ordinary biodiversity and what we could call, by analogy, the ordinary darkness, i.e., the darkness whose protection does not depend on the implementation of zoning that establishes a specific protection status. Extending the fight against light pollution means spreading the protection of darkness and biodiversity beyond protected areas alone, symbolically represented by areas overhung by an exceptional starry sky, even in ordinary areas. The reticular 
approach proposed via the dark ecological network takes this twofold ecological and geographical direction: it aims to make the protection of the darkness/biodiversity couple a new guiding principle for land use planning.

\section{FROM A SCIENTIFIC CONCEPT TO AN ACTION- ORIENTED TOOL: FACING THE TERRITORIALIZATION CHALLENGE}

By emphasizing the importance of darkness as a new dimension of ecological connectivity, the concept of dark ecological network operates nothing less than a radical reframing of the fight against light pollution. It requires a shift in darkness preservation views and objectives, from a vertical, aesthetic, and quasi-pictorial landscape - the nightscape and its "artialized" (Roger 1997) starry sky, contemplated like a painting in a way that is dissociative from the self - to a horizontal and holistic landscape. This holistic landscape is part of the "real world" (Battisti 2003) and thus becomes the boundary object (Brand and Jax 2007) between the modality of scientific analysis and the modality of public action. Achieving this change in perspective is the challenge of the territorialization of the dark ecological network, whose practical implications stem from this holistic and geographically situated approach of the nocturnal social-ecological systems.

\section{Territorialization, a multilevel process to counteract scales mismatches}

According to Dessein (2015:108), "we use the notion of 'territorialization' to describe the dynamics and processes in the context of regional development that are driven by collective human intentionality; these stretch beyond localities and fixed regional boundaries (Horlings et al. 2015)." De facto, any territorialization process involves a multiscalar, multiactor, and multisector approach. The problem of mismatch between the scales of ecological processes and the stakeholders responsible for their management is well known (Borgström et al. 2006, Cash et al. 2006, Cumming et al. 2006, Folke et al. 2007). This problem is particularly acute when dealing with diffuse pollution such as light pollution, radically multiscalar in both its causes and consequences. Here, and as Borgström et al. (2006) and others since the 1990's (Lee 1993, Holling and Meffe 1996, Hobbs 1998) point out, "the scale of monitoring and decision making often does not match ecological spatial, temporal, or functional scales." These scale mismatches result in a mismanagement of natural resources. Among mitigating solutions, Cumming et al. (2006) emphasize the "institutional changes at more than one hierarchical level" and show that these changes are dependent on "social learning and the development of flexible institutions that can adjust and reorganize in response to changes in ecosystems."

We understand territorialization as the process of situated objectification that organizes the pairing of positivist and constructivist epistemologies at the service of environmental action. The territorialization process confronts scientific knowledge with institutional struggles and cooperation, but also with vernacular knowledge and other forms of attachment to places (Sébastien 2020) in order to make them operational. In a logic and context of uncertainty, territorialization thus aims at articulating the knowledge scales - understood as "the temporal and spatial extent and character of knowledge held by individuals and collectives" (Ahlborg and Nightingale 2012) - to the spatial, institutional, and temporal scales. Thus stated, the territorialization process is close to both adaptive governance (Folke et al. 2005)—whose relevance to solving the scales mismatch within social-ecological systems has been demonstrated by Termeer et al. (2010) — and multilevel governance. However, territorialization is more critical with regard to foundations and the meaning of pre-existing governance systems. In other words, territorialization leaves open the possibility of questioning the institutional governance frameworks, because it considers the meaning of places and relationships to lived spaces as facts that must be taken into account when defining instruments for preserving biodiversity. For this reason, we argue that debate and the proximity of decision making and citizen involvement are then consubstantial with the territorialization of the ecological network.

\section{Building repositories of contextualized scientific knowledge}

The territorialization process is necessarily a situated and actionoriented approach. It is situated because it takes into consideration the different dimensions that structure the territory and the distinctiveness of places for sustainable development, e. g., cultural, historical, political, physical, or ecological dimensions (Horlings 2015). It is action-oriented because it focuses on bringing together researchers, residents, politicians, practitioners, user groups, environmental associations, and experts.

Thinking about the protection of darkness beyond protected areas alone poses the difficulty of confronting the multiple nocturnal uses and the planning choices that have been made at different territorial scales. The transition from a scientific concept to a territorial and political project is therefore a problematic situation, in that it places scientific and territorial constraints under stress. Negotiations and arbitrations, particularly in terms of artificial lighting management, respect for human uses, and choice of species to be protected, preside over the production of the dark ecological network and reflect its socio-ecosystemic complexity. The territorialization and operationalization of the dark ecological network require a reflexivity effort on the part of both scientists and territorial actors. It is reflected in a change in practices on both sides. This reflexivity effort can be illustrated by the cartography of the dark ecological network. This work relies on combining the "knowledge, techniques and realities of the territory in order to organize the transition from the concept to the development of concrete projects" (Vimal and Mathevet 2011). In concrete terms, the cartographic definition of the ecological network must integrate value systems and representations linked to territories' historical, social, economic, political, and symbolic dimensions (Mascia et al. 2003, Blicharska et al. 2016). Social sciences tools and methodologies make it possible to probe this territorial thickness by analyzing connections between the spaces and actors involved in the protection of the darkness and biodiversity couple (Challéat and Lapostolle 2014). By examining, as well, the mediation logics at work in lighting policies local redefinitions (Lapostolle et al. 2015, Lapostolle and Challéat 2021), the integration of biodiversity issues into public controversies and debates, social, economic, and scientific issues related to the protection of nocturnal spaces and species, or pioneering practices that foreshadow new forms of organizing nocturnal socio-ecosystems. 
Fig. 2. Conceptual blueprint of the structural components of the dark ecological network.

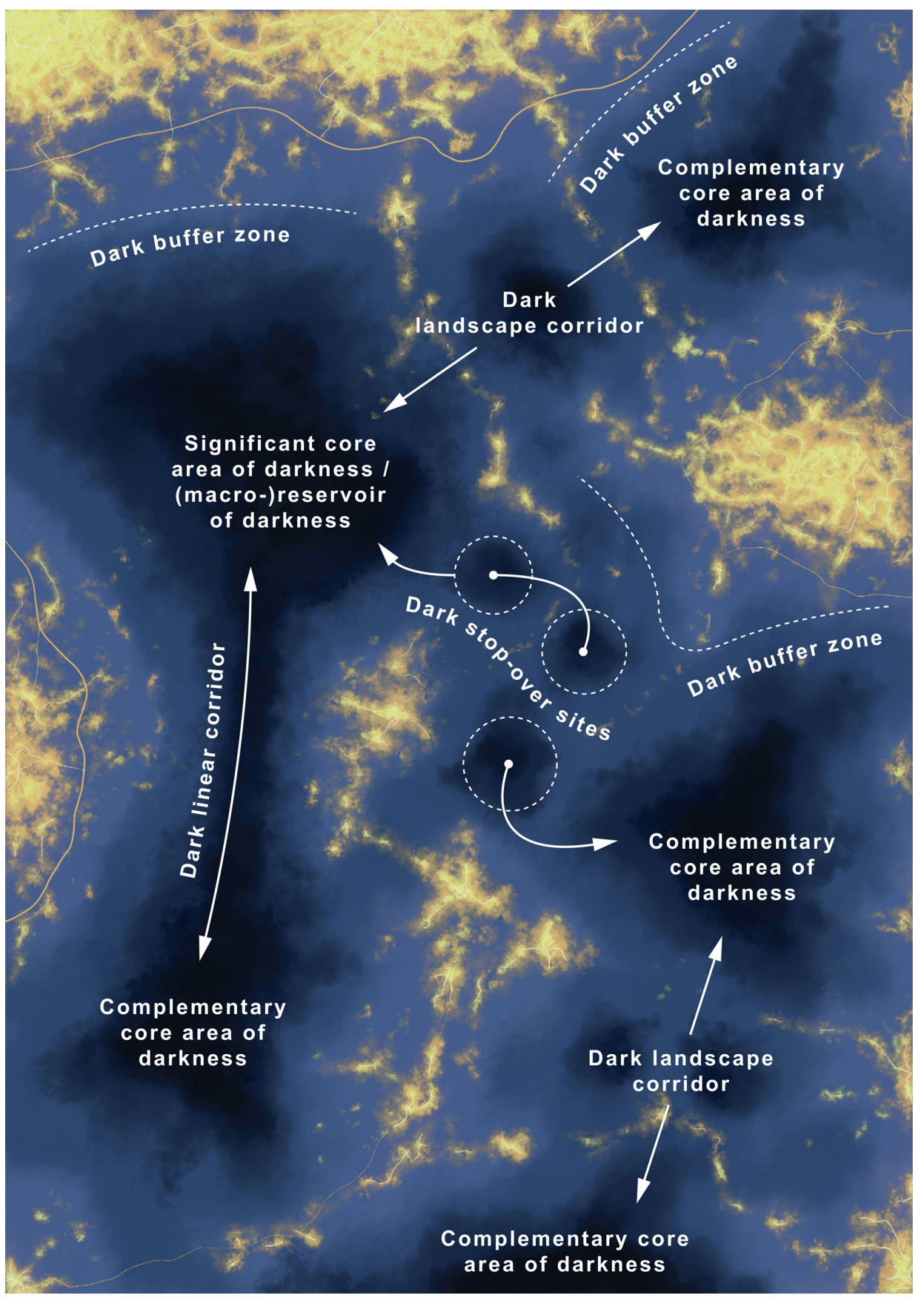

However, while objective knowledge of territorial specificities is necessary to inform action, it is likely not sufficient. The experiential relationships to nature expressed by inhabitants and users, i.e., vernacular knowledge, must be integrated into the repertoire of situated scientific knowledge, in order to guarantee the balanced governance of the dark ecological network.

The experience of nature as the basis of dark ecological network governance

Public policy decision making is based on different knowledge repositories. In the perspective of classical evidence-based policy making, the repertoire of objective knowledge predominates Now, because we wish to territorialize public environmental policies, several recent studies show that it is necessary to integrate into their governance the actors holding other knowledge repositories: citizens, resource users, policy makers, and practitioners, for example (Cornell et al. 2013, Leach et al. 2013, Díaz et al. 2015). This is the challenge of the multiple evidencebased approach developed by Tengö et al. (2014, 2017), which recognizes as complementary different knowledge systems with distinct epistemic properties, and aims to link them in action. This 
approach requires a broader construction of the "public of the problem" (Dewey 1927) and the creation of conditions for participation in its governance (Zask 2011). This "common decision-making process" is the meaning we give to the dark ecological network as a political method to recognize the diversity of nature experiences (Skandrani and Prévot 2015). Considered this way, the dark ecological network is no longer just a scientific concept, but becomes the preferred vehicle for restoring within our everyday lives the experience of darkness in ordinary places (Miller 2006), even in (peri-)urban spaces. In other words, and whatever the types of spaces considered, darkness preservation gives access to a range of experiences that permit a sensitive understanding of the world.

Such sensitive understanding of the world is permeable to environmental issues. Therefore, and even in urbanized spaces, night appears as the daily scene of multiple experiential dimensions of nature and biodiversity (Bogard 2008, 2013, Challéat 2019), as well as to oneself. Emotional dimensions include some of our atavistic fears (Painter 1996, Schaller et al. 2003, Koslofsky 2011), but also sensory, memorial, analogical, or utilitarian dimensions (Prévot et al. 2016). These experiences are a tangible basis for debating artificial light at night in the face of darkness. These multiple dimensions make darkness a multifaceted resource, e.g., naturalistic, poetic, literary, philosophical, religious, landscape, scientific, or artistic, that participates as much in our individuation and in the constitution of our relationship to the world as in the fabric of the territories (Challéat et al. 2018). It thus gives meaning to places (Barreteau et al. 2016, Sébastien 2020). However, the governance of artificial light at night, by neglecting these different meanings of the resource, spatially and temporally erodes darkness and impoverishes the relationships that our societies maintain with the nocturnal environment. In this way, it deprives itself of a number of solutions to preserve darkness and to support consensus on how to preserve it at local level (Fig. 1).

In order to work, this holistic, integrated, and situated approach of darkness conservation must be built within hybrid forums (Callon et al. 2001) allowing the expression of the plurality of experiential relationships. The teachings and lessons learned from the difficulties encountered in the territorialization of other forms of public environmental actions or policies ought to be heeded (Franchomme et al. 2013). In other words, learning effects (Baird et al. 2014) should be carefully considered in order to better "bring science into democracy" (Latour 2004), especially with respect to "new" environmental problems such as light pollution. In France, for example, when identifying biodiversity reservoirs and ecological corridors at the territorial level as part of the Trame Verte et Bleue (TVB) policy, the French strategy to operationalize the concept of ecological network (see https://www.ecologiquesolidaire.gouv.fr/trame-verte-et-bleue), several studies have highlighted "the difficulty of involving field actors alongside modeling experts. The mobilization of the latter's sophisticated tools has not been accompanied with consideration for other forms of knowledge or a contradictory debate, despite the criticisms and limitations pointed out by the actors in the field about the method used" (Alphandéry and Fortier 2012). The local anchoring of the TVB has been built through different communication, translation, and advertising processes involving different stakeholders, in order to become accessible and appropriable by the greatest number of people. Political action is complex here. The lessons learned from the implementation of the TVB policy can be valuable for the dark ecological network territorialization. More particularly to bridge the gap between scientific knowledge and action and to deepen the links between multilevel governance and participatory processes. The territorialization of the dark ecological network aims to considerably change the living environment of the inhabitants and users of the spaces. It must therefore be debated in arenas whose access is not restricted to scientists. Moving beyond the technical approach to the problem and initiating a real project approach (Janin et al. 2011) to darkness conservation can, for example, involve transdisciplinarity. This makes it possible to (re) integrate research, action, and policy (Leach et al. 2013). By creating the conditions for participation, transdisciplinarity brings together researchers, residents, politicians, practitioners, user groups, environmental associations, and experts.

At the European level, we can see the embryos of these transdisciplinary practices within Interreg programs (Interreg Europe "Night Light," Interreg Poctefa "Pirineos La Nuit," or Interreg Großregion "Smarth Light Hub"). These programs experiment with the implementation of conferences-debates, hybridization, and cocreation workshops, or the setting up of demonstrators for the inhabitants and elected officials of the territories. More broadly, these experimental transdisciplinary approaches could be applied to changes in lighting practices in and around Natura 2000 sites, which currently do not consider the issue of light pollution. Indeed, although European texts are clear on the need for member states to ensure the ecological connectivity of their sites, they are not very prescriptive on how to achieve this. Taking into account the issues raised by ALANrelated impacts in the Natura 2000 policy would be an opportunity to clarify its territorialization framework. These approaches could then provide a pragmatic basis for regulating this area of public action. It would address scientific and technological issues, providing they allow, on the one hand, diverse stakeholders' involvement in the local production of the dark ecological network and, on the other hand, researchers' commitment to the democratic and political process (Fischer 2000, Reed 2008; B. V. Lewenstein 2004, unpublished manuscript, http://hdl.handle.net/1813/37362). What matters then is not to abandon a method that establishes facts and recognizes territories' singularity (Vimal et al. 2012) without giving way to the performative dimension of public policy instruments in general and of the dark ecological network in particular.

\section{CONCLUSION}

Building on the ecological network framework, the dark ecological network aims to consider artificial light at night as a driver of habitat fragmentation, to further integrate the nocturnal dynamics of ecological processes into biodiversity conservation planning, and to deepen and extend the fight against light pollution to ordinary biodiversity and familiar areas. The dark ecological network success is therefore dependent on including the logic of preserving darkness in the ordinary practices of environmental planning and development of all territories. Such trivialization of darkness protection gives rise to new needs. It requires the deployment of integrated darkness conservation, paying attention to the multiple uses, both human and nonhuman, of nocturnal space and time or, in other words, the deployment 
of a conservation method that falls within the realm of political ecology and fits in with the concept of ecological solidarity (Mathevet et al. 2016) as a profound consideration of "the 'community of destiny' between humans, society and its environment" (Mathevet et al. 2010:426 [our translation]). This approach to darkness protection can only be deployed within a relational thinking framework that, within the preservation of living diversity systems, integrates the interaction of ecological systems on the one hand, and social systems on the other. In other words, the trivialization of the darkness/biodiversity couple protection through the dark ecological network is a radically social-ecological approach that aims to (re)define the nocturnal living space that a society agrees to share with the nonhumans among which it evolves. It provides a relevant framework for pragmatic action, which "requires establishing and organizing social relationships, while communicating and discussing values, ends and means" (Mathevet 2012:150 [our translation]) that underlie the geographically situated action.

Various experiences designed to define and implement the dark ecological network in France show that issues of protecting darkness to meet biodiversity challenges are gradually being addressed in land use planning policies (Challéat et al. 2018, Franchomme et al. 2019). However, passing from these experiments in a few pioneering territories to their transcription into the ordinary areas is a long way down the road. It requires rethinking both terms when analyzing the relationship between societies and the environment, as well as the conditions in which land use planning is implemented. A serious approach is emerging, which brings together the tradition of ecological research with the common practice of social geography in territories (Barreteau et al. 2016). In other words, experimental sciences and social sciences are making progress in bringing their analytical questions and methods closer together, thus catalyzing the translation of scientific ecology into political ecology (Devictor 2018a, b). Interdisciplinary social-ecological approaches are emerging as a new scientific paradigm. However, the challenge remains: how to go about it, i.e., applying these analyses to territorially situated planning policies. Here, knowledge production methods (participatory sciences, citizen sciences, action research, and engaged research) are shaking up (because they question them) the social significance of scientific knowledge and the practical experience of land use planning professionals. Yet, here as elsewhere, the "inescapable distinction between emic and etic, or between learned and common sense, should not mean superiority of one over the other or ignorance of one by the other" (Olivier de Sardan 1988:536 [our translation]). Doing so, they highlight the need for a more general appropriation of ecological transition and biodiversity protection policies. It is a paradigm shift that requires recognizing that scientific controversies and sustainability are political issues and, as such, requires an inclusive debate and a plurality of voices (Leach et al. 2013).

Responses to this article can be read online at: https://www.ecologyandsociety.org/issues/responses. php/12156

\section{Acknowledgments:}

This work was cofunded by the LabEx DRIIHM (French programme "Investissements d'Avenir" ANR-11-LABX-0010, which is managed by the ANR), by the ITTECOP (Land transport infrastructure, ecosystems, and landscapes) CHIROLUM programme, and by the "TRAME NOIRE" project (funded by the "Conseil Régional Nord-Pas-de-Calais" and by "Fondation pour la Recherche sur la Biodiversité").

\section{LITERATURE CITED}

ADEME, AFE, Syndicat de l'éclairage. 2010. Éclairer juste. ADEME, Angers, France. [online] URL: https://www.ademe.fr/ sites/default/files/assets/documents/74511 7038 72dpi eclairerjuste. pdf

Ahlborg, H., and A. J. Nightingale. 2012. Mismatch between scales of knowledge in Nepalese forestry: epistemology, power, and policy implications. Ecology and Society 17(4):16. https://doi. org/10.5751/ES-05171-170416

Alphandéry, P., and A. Fortier. 2012. La trame verte et bleue et ses réseaux: science, acteurs et territoires. VertigO - La revue électronique en sciences de l'environnement 12(2). https://doi. org/10.4000/vertigo. 12453

Alphandéry, P., A. Fortier, and A. Sourdril. 2012. Les données entre normalisation et territoire : la construction de la trame verte et bleue. [Naturalist data between standards and territory : building ecological network (TVB) in France]. Développement durable et territoires. Économie, géographie, politique, droit, sociologie 3(2). https://doi.org/10.4000/developpementdurable.9282

Altermatt, F., and D. Ebert. 2016. Reduced flight-to-light behaviour of moth populations exposed to long-term urban light pollution. Biology Letters 12(4):3-6. https://doi.org/10.1098/ rsbl.2016.0111

Azam, C., C. Kerbiriou, A. Vernet, J.-F. Julien, Y. Bas, L. Plichard, J. Maratrat, and I. Le Viol. 2015. Is part-night lighting an effective measure to limit the impacts of artificial lighting on bats? Global Change Biology 21(12):4333-4341. https://doi.org/10.1111/ gcb. 13036

Azam, C., I. Le Viol, Y. Bas, G. Zissis, A. Vernet, J.-F. Julien, and C. Kerbiriou. 2018. Evidence for distance and illuminance thresholds in the effects of artificial lighting on bat activity. Landscape and Urban Planning 175:123-135. https://doi. org/10.1016/j.landurbplan.2018.02.011

Azam, C., I. Le Viol, J.-F. Julien, Y. Bas, and C. Kerbiriou. 2016. Disentangling the relative effect of light pollution, impervious surfaces and intensive agriculture on bat activity with a nationalscale monitoring program. Landscape Ecology 31(10):2471-2483. https://doi.org/10.1007/s10980-016-0417-3

Baird, J., R. Plummer, C. Haug, and D. Huitema. 2014. Learning effects of interactive decision-making processes for climate change adaptation. Global Environmental Change 27:51-63. https://doi.org/10.1016/j.gloenvcha.2014.04.019 
Barré, K., K. Spoelstra, Y. Bas, S. Challéat, R. Kiri Ing, C. Azam, G. Zissis, D. Lapostolle, C. Kerbiriou, and I. Le Viol. 2020. Artificial light may change flight patterns of bats near bridges along urban waterways. Animal Conservation. https://doi. org/10.1111/acv.12635

Barreteau, O., D. Giband, M. Schoon, J. Cerceau, F. DeClerck, S. Ghiotti, T. James, V. Masterson, R. Mathevet, S. Rode, F. Ricci, and C. Therville. 2016. Bringing together social-ecological system and territoire concepts to explore nature-society dynamics. Ecology and Society 21(4):42. https://doi.org/10.5751/ES-08834-210442

Battisti, C. 2003. Habitat fragmentation, fauna and ecological network planning: toward a theoretical conceptual framework. Italian Journal of Zoology 70(3):241-247. https://doi. org/10.1080/11250000309356524

Bennett, G., and P. Wit. 2001. The development and application of ecological networks: a review of proposals, plans and programmes. AIDEnvironment, Amsterdam, The Netherlands.

Bennie, J., T. W. Davies, D. Cruse, F. Bell, and K. J. Gaston. $2018 b$. Artificial light at night alters grassland vegetation species composition and phenology. Journal of Applied Ecology 55 (1):442-450. https://doi.org/10.1111/1365-2664.12927

Bennie, J., T. W. Davies, D. Cruse, R. Inger, and K. J. Gaston. 2018a. Artificial light at night causes top-down and bottom-up trophic effects on invertebrate populations. Journal of Applied Ecology 55(6):2698-2706. https://doi.org/10.1111/1365-2664.13240

Bénos, R., S. Challéat, D. Lapostolle, P.-O. Dupuy, T. Poméon, J. Milian, and F. Girard. 2016. La protection de la nuit d'un haut lieu touristique de montagne: la Réserve internationale de ciel étoilé du Pic du Midi comme nouvelle ressource territoriale. Pages 55-82 in M. Delaplace and M. Gravari-Barbas, editors. Nouveaux territoires touristiques. Presses de l'Université du Québec, Québec, Canada. https://doi.org/10.2307/j.ctt1mf6z6s.7

Bird, B. L., L. C. Branch, and D. L. Miller. 2004. Effects of coastal lighting on foraging behavior of beach mice. Conservation Biology 18(5):1435-1439. https://doi.org/10.1111/j.1523-1739.2004.00349. $\underline{\mathrm{X}}$

Bischoff, N. T., and R. H. G. Jongman. 1993. Development of rural areas in Europe: the claim for nature. Netherlands Scientific Council for Government Policy, The Hague, The Netherlands. [online] URL: https://english.wrr.n1/publications/publications/1993/09/21/ development-of-rural-areas-in-europe-the-claim-for-nature

Blicharska, M., E. H. Orlikowska, J. M. Roberge, and M. Grodzinska-Jurczak. 2016. Contribution of social science to large scale biodiversity conservation. A review of research about the Natura 2000 network. Biological Conservation 199:110-122. https://doi.org/10.1016/j.biocon.2016.05.007

Blundell, E., V. Schaffer, and B. D. Moyle. 2020. Dark sky tourism and the sustainability of regional tourism destinations. Tourism Recreation Research 45(4):549-556. https://doi.org/10.1080/0250$\underline{8281.2020 .1782084}$

Bogard, P. 2008. Let there be night: testimony on behalf of the dark. University of Nevada Press, Reno, Nevada, USA.

Bogard, P. 2013. The end of night: searching for natural darkness in an age of artificial light. Hachette, London, UK.
Boitani, L., A. Falcucci, L. Maiorano, and C. Rondinini. 2007. Ecological networks as conceptual frameworks or operational tools in conservation. Conservation Biology 21(6):1414-1422. https://doi.org/10.1111/j.1523-1739.2007.00828.x

Borgström, S. T., T. Elmqvist, P. Angelstam, and C. AlfsenNorodom. 2006. Scale mismatches in management of urban landscapes. Ecology and Society 11(2):16. https://doi.org/10.5751/ es-01819-110216

Brainard, G. C., J. P. Hanifin, J. M. Greeson, B. Byrne, G. Glickman, E. Gerner, and M. D. Rollag. 2001. Action spectrum for melatonin regulation in humans: evidence for a novel circadian photoreceptor. Journal of Neuroscience 21(16):6405-6412. https:// doi.org/10.1523/JNEUROSCI.21-16-06405.2001

Brand, F. S., and K. Jax. 2007. Focusing the meaning(s) of resilience: resilience as a descriptive concept and a boundary object. Ecology and Society 12(1):23. https://doi.org/10.5751/ ES-02029-120123

Brox, J. 2010. Brilliant: the evolution of artificial light. Houghton Mifflin Harcourt, New York, New York, USA.

Cajochen, C., J. M. Zeitzer, C. A. Czeisler, and D. J. Dijk. 2000. Dose-response relationship for light intensity and ocular and electroencephalographic correlates of human alertness. Behavioural Brain Research 115(1):75-83. https://doi.org/10.1016/ $\underline{\text { S0166-4328(00)00236-9 }}$

Callon, M., P. Lascoumes, and Y. Barthe. 2001. Agir dans un monde incertain. Essai sur la démocratie représentative. Seuil, Paris, France.

Cash, D. W., W. Adger, F. Berkes, P. Garden, L. Lebel, P. Olsson, L. Pritchard, and O. Young. 2006. Scale and cross-scale dynamics: governance and information in a multilevel world. Ecology and Society 11(2):8. https://doi.org/10.5751/es-01759-110208

Challéat, S. 2019. Sauver la nuit. Comment l'obscurité disparaît, ce que sa disparition fait au vivant, et comment la reconquérir. Premier Parallèle, Paris, France.

Challéat, S., and D. Lapostolle. 2014. (Ré)concilier éclairage urbain et environnement nocturne: les enjeux d'une controverse sociotechnique. Natures Sciences Sociétés 22(4):317-328. https:// doi.org/10.1051/nss/2014045

Challéat, S., and D. Lapostolle. 2018. Getting night lighting right: taking account of nocturnal urban uses for better-lit cities. Metropolitics, 2 November. [online] URL: https://www. metropolitiques.eu/Getting-Night-Lighting-Right.html

Challéat, S., D. Lapostolle, and J. Milian. 2018. The nighttime environment in French mountain areas. A resource and a transition operator towards sustainability. Journal of Alpine Research | Revue de géographie alpine 106(1). https://doi. org/10.4000/rga.3947

Challéat, S., and T. Poméon. 2020. "And what do you do with five-hundred million stars?" Assessment of darkness and the starry sky, values and integration in regional planning. Chapter 10 in S. Saville and G. Hoskins, editors. Locating value: theory, application and critique. Routledge, London, UK. https://doi. org/10.4324/9781315723686-10 
Chang, A.-M., N. Santhi, M. St Hilaire, C. Gronfier, D. S. Bradstreet, J. F. Duffy, S. W. Lockley, R. E. Kronauer, and C. A. Czeisler. 2012. Human responses to bright light of different durations. Journal of Physiology 590(13):3103-3112. https://doi. org/10.1113/jphysiol.2011.226555

Chapin III, F. S., and C. N. Knapp. 2015. Sense of place: a process for identifying and negotiating potentially contested visions of sustainability. Environmental Science \& Policy 53:38-46. https:// doi.org/10.1016/j.envsci.2015.04.012

Charlier, B., and N. Bourgeois. 2013. "Half the park is after dark". Dark sky parks and reserves: new concepts and tools to grant nature heritage status. Espace géographique (English Edition) 42 (3):186-198. https://doi.org/10.3917/eg.423.0200

Collison, F. M., and K. Poe. 2013. "Astronomical tourism": the astronomy and dark sky program at Bryce Canyon National Park. Tourism Management Perspectives 7:1-15. https://doi.org/10.1016/ j.tmp.2013.01.002

Cornell, S., F. Berkhout, W. Tuinstra, J. D. Tàbara, J. Jäger, I. Chabay, B. de Witt, R. Langlais, D. Mills, P. Moll, I. M. Otto, A, Petersen, C. Pohl, and L. van Kerkoff. 2013. Opening up knowledge systems for better responses to global environmental change. Environmental Science \& Policy 28:60-70. https://doi. org/10.1016/j.envsci.2012.11.008

Cumming, G. S., D. H. M. Cumming, and C. L. Redman. 2006. Scale mismatches in social-ecological systems: causes, consequences, and solutions. Ecology and Society 11(1):14. https://doi.org/10.5751/ES-01569-110114

Davies, T. W., J. Bennie, D. Cruse, D. Blumgart, R. Inger, and K. J. Gaston. 2017. Multiple nighttime light-emitting diode lighting strategies impact grassland invertebrate assemblages. Global Change Biology 23(7):2641-2648. https://doi.org/10.1111/gcb.13615

Davies, T. W., J. Bennie, and K. J. Gaston. 2012. Street lighting changes the composition of invertebrate communities. Biology Letters 8(5):764-767. https://doi.org/10.1098/rsbl.2012.0216

Davies, T. W., J. Bennie, R. Inger, and K. J. Gaston. 2013. Artificial light alters natural regimes of nighttime sky brightness. Scientific Reports 3:1722. https://doi.org/10.1038/srep01722

de Jong, M., L. Jeninga, J. Q. Ouyang, K. van Oers, K. Spoelstra, and M. E. Visser. 2016. Dose-dependent responses of avian daily rhythms to artificial light at night. Physiology and Behavior 155:172-179. https://doi.org/10.1016/j.physbeh.2015.12.012

De Jong, M., J. Q. Ouyang, A. Da Silva, R. H. van Grunsven, B. Kempenaers, M. E. Visser, and K. Spoelstra. 2015. Effects of nocturnal illumination on life-history decisions and fitness in two wild songbird species. Philosophical Transactions of the Royal Society B: Biological Sciences 370(1667):20140128. https://doi. org/10.1098/rstb.2014.0128

Dessein, J. 2015. Territorialisation in practice: the case of saffron cultivation in Morocco. Pages 108-124 in J. Dessein, E. Battaglini, and L. Horlings, editors. Cultural sustainability and regional development. Theories and practices of territorialisation. Routledge, London, UK. https://doi.org/10.4324/9781315737430
Devictor, V. 2018a. La prise en charge technoscientifique de la crise de la biodiversité. Dissertation. Université Panthéon-SorbonneParis, France.

Devictor, V. 2018b. La compensation écologique: fondements épistémiques et reconfigurations technoscientifiques [Biodiversity offsetting: epistemic background and technoscientific reframing]. Natures Sciences Sociétés 26(2):136-149. https://doi.org/10.1051/ $\underline{\mathrm{nss} / 2018032}$

Dewey, J. 1927. The public and its problems. Holt, New York, New York, USA.

Díaz, S., S. Demissew, J. Carabias, C. Joly, M. Lonsdale, N. Ash, A. Larigauderie, J. Ram Adhikari, S. Arico, A. Báldi, et al. 2015. The IPBES conceptual framework - connecting nature and people. Current Opinion in Environmental Sustainability 14:1-16.

Dudley, N. 2008. Guidelines for applying IUCN protected area categories. International Union for Conservation of Nature, Gland, Switzerland.

Edensor, T. 2013. Reconnecting with darkness: gloomy landscapes, lightless places. Social \& Cultural Geography 14 (4):446-465. https://doi.org/10.1080/14649365.2013.790992

Edensor, T. 2015. The gloomy city: rethinking the relationship between light and dark. Urban Studies 52(3):422-438. https://doi. org/10.1177/0042098013504009

Eisenbeis, G. 2006. Artificial night lighting and insects: attraction of insects to streetlamps in a rural setting in Germany. Pages 281-304 in C. Rich and T. Longcore, editors. Ecological consequences of artificial night lighting. Island, Washington, D. C., USA. https://doi.org/10.1017/CBO9780511609763.016

European Commission. 2013. Communication from the Commission to the European Parliament, the Council, the European Economic and Social Committee and the Committee of the Regions. Green Infrastructure (GI) - Enhancing Europe's Natural Capital. European Commission, Brussels, Belgium. [online] URL: https://eur-lex.europa.eu/resource.html?uri=cellar: d41348f2-01d5-4abe-b817-4c73e6f1b2df.0014.03/DOC 1\&format= PDF

Falchi, F. 2018. Light pollution. Pages 147-159 in S. M. Charlesworth and C. A. Booth, editors. Urban pollution: science and management. John Wiley \& Sons, Hoboken, New Jersey, USA. https://doi.org/10.1002/9781119260493.ch11

Falchi, F., P. Cinzano, D. Duriscoe, C. C. M. Kyba, C. D. Elvidge, K. Baugh, B. A. Portnov, N. A. Rybnikova, and R. Furgoni. 2016. The new world atlas of artificial night sky brightness. Science Advances 2(6):e1600377. https://doi.org/10.1126/sciadv.1600377

Falcón, J., A. Torriglia, D. Attia, F. Viénot, C. Gronfier, F. BeharCohen, C. Martinsons, and D. Hicks. 2020. Exposure to artificial light at night and the consequences for flora, fauna, and ecosystems. Frontiers in Neuroscience 14:602796. https://doi. org/10.3389/fnins.2020.602796

Fischer, F. 2000. Citizens, experts, and the environment. The politics of local knowledge. Duke University Press, Durham, North Carolina, USA. https://doi.org/10.1215/9780822380283 
Fischer, J., and D. B. Lindenmayer. 2007. Landscape modification and habitat fragmentation: a synthesis. Global Ecology and Biogeography 16(3):265-280. https://doi.org/10.1111/ j.1466-8238.2007.00287.x

Folke, C., T. Hahn, P. Olsson, and J. Norberg. 2005. Adaptive governance of social-ecological systems. Annual Review of Environment and Resources 30:441-473. https://doi.org/10.1146/ annurev.energy.30.050504.144511

Folke, C., L. Pritchard Jr, F. Berkes, J. Colding, and U. Svedin. 2007. The problem of fit between ecosystems and institutions: ten years later. Ecology and Society 12(1):30. https://doi.org/10.5751/ ES-02064-120130

Franchomme, M., M. Bonnin, and C. Hinnewinkel. 2013. La biodiversité "aménage-t-elle" les territoires? Vers une écologisation des territoires. Développement durable et territoires. Économie, géographie, politique, droit, sociologie 4(1). https://doi. org/10.4000/developpementdurable.9749

Franchomme, M., C. Hinnewinkel, and S. Challéat. 2019. La trame noire, un indicateur de la place de la nature dans l'aménagement du territoire. Pratiques et motivations des communes de la Métropole européenne de Lille. Bulletin de l'association de géographes français 96(96-2):161-180. https://doi. org/10.4000/bagf.4764

Galinier, J., A. Monod Becquelin, G. Bordin, L. Fontaine, F. Fourmaux, J. Roullet Ponce, P. Salzarulo, P. Simonnot, M. Therrien, and I. Zilli. 2010. Anthropology of the night: crossdisciplinary investigations. Current Anthropology 51(6):819-847. https://doi.org/10.1086/653691

Gallaway, T. 2010. On light pollution, passive pleasures, and the instrumental value of beauty. Journal of Economic Issues 44 (1):71-88. https://doi.org/10.2753/JEI0021-3624440104

Gaston, K. J., T. W. Davies, J. Bennie, and J. Hopkins. 2012. Reducing the ecological consequences of nighttime light pollution: options and developments. Journal of Applied Ecology 49(6):1256-1266. https://doi.org/10.1111/j.1365-2664.2012.02212. $\underline{\mathrm{X}}$

Gaston, K. J., T. W. Davies, S. L. Nedelec, and L. A. Holt. 2017. Impacts of artificial light at night on biological timings. Annual Review of Ecology, Evolution, and Systematics 48(1):49-68. https:// doi.org/10.1146/annurev-ecolsys-110316-022745

Gaston, K. J., M. E. Visser, and F. Hölker. 2015. The biological impacts of artificial light at night: the research challenge. Philosophical Transactions of the Royal Society B: Biological Sciences 370(20140133). https://doi.org/10.1098/rstb.2014.0133

Gronfier, C., K. P. Wright Jr, R. E. Kronauer, M. E. Jewett, and C. A. Czeisler. 2004. Efficacy of a single sequence of intermittent bright light pulses for delaying circadian phase in humans. American Journal of Physiology-Endocrinology and Metabolism 287(1):E174-E181. https://doi.org/10.1152/ajpendo.00385.2003

Grubisic, M., G. Singer, M. C. Bruno, R. H. van Grunsven, A. Manfrin, M. T. Monaghan, and F. Hölker. 2017. Artificial light at night decreases biomass and alters community composition of benthic primary producers in a sub-alpine stream. Limnology and Oceanography 62(6):2799-2810. https://doi.org/10.1002/lno.10607
Guetté, A., L. Godet, M. Juigner, and M. Robin. 2018. Worldwide increase in artificial light at night around protected areas and within biodiversity hotspots. Biological Conservation 223:97-103. https://doi.org/10.1016/j.biocon.2018.04.018

Hale, J. D., A. J. Fairbrass, T. J. Matthews, G. Davies, and J. P. Sadler. 2015. The ecological impact of city lighting scenarios: exploring gap crossing thresholds for urban bats. Global Change Biology 21(7):2467-2478. https://doi.org/10.1111/gcb.12884

Hansen, A. J., and R. DeFries. 2007. Ecological mechanisms linking protected areas to surrounding lands. Ecological Applications 17(4):974-988. https://doi.org/10.1890/05-1098

Hausmann, A., R. O. B. Slotow, J. K. Burns, and E. Di Minin. 2016. The ecosystem service of sense of place: benefits for human well-being and biodiversity conservation. Environmental Conservation 43(2):117-127. https://doi.org/10.1017/S0376892915000314

Hobbs, R. J. 1998. Managing ecological systems and processes. Pages 459-484 in D. L. Peterson and V. T. Parker, editors. Ecological scale. Theory and applications. Columbia University Press, New York, New York, USA.

Hölker, F., C. Wolter, E. K. Perkin, and K. Tockner. 2010. Light pollution as a biodiversity threat. Trends in Ecology and Evolution 25(12):681-682. https://doi.org/10.1016/j.tree.2010.09.007

Holling, C. S., and G. K. Meffe. 1996. Command and control and the pathology of natural resource management. Conservation Biology (10):328-337. https://doi.org/10.1046/j.1523-1739.1996.10020328. $\underline{\mathrm{x}}$

Hopkins, G. R., K. J. Gaston, M. E. Visser, M. A. Elgar, and T. M. Jones. 2018. Artificial light at night as a driver of evolution across urban-rural landscapes. Frontiers in Ecology and the Environment 16(8):472-479. https://doi.org/10.1002/fee.1828

Horlings, L. G. 2015. Values in place; a value-oriented approach toward sustainable place-shaping. Regional Studies, Regional Science 2(1):257-274. https://doi.org/10.1080/21681376.2015.1014062

Horton, K. G., C. Nilsson, B. M. Van Doren, F. A. La Sorte, A. M. Dokter, and A. Farnsworth. 2019. Bright lights in the big cities: migratory birds' exposure to artificial light. Frontiers in Ecology and the Environment 17(4):209-214. https://doi.org/10.1002/ fee.2029

Isobe, S., and T. Hirayama. 1998. Preserving the astronomical windows. Proceedings of Joint Discussion Number 5 of the 23rd General Assembly of the International Astronomical Union, Kyoto, Japan, 22-23 August 1997. Astronomical Society of the Pacific, San Francisco, California, USA.

Janin, C., E. Grasset, D. Lapostolle, and E. Turquin. 2011. L'ingénierie, signe d'intelligence territoriale? EconomicaAnthropos, Paris, France.

Jongman, R. H. 1995. Nature conservation planning in Europe: developing ecological networks. Landscape and Urban Planning 32(3):169-183. https://doi.org/10.1016/0169-2046(95)00197-O

Jongman, R. H. 2002. Homogenisation and fragmentation of the European landscape: ecological consequences and solutions. Landscape and Urban Planning 58(2-4):211-221. https://doi. org/10.1016/S0169-2046(01)00222-5 
Jongman, R. H., I. M. Bouwma, A. Griffioen, L. Jones-Walters, and A. M. Van Doorn. 2011. The pan European ecological network: PEEN. Landscape Ecology 26(3):311-326. https://doi. org/10.1007/s10980-010-9567-X

Jongman, R. H., and I. Kristiansen. 2001. National and regional approaches for ecological networks in Europe. Council of Europe, Strasbourg, France.

Jongman, R. H., M. Külvik, and I. Kristiansen. 2004. European ecological networks and greenways. Landscape and Urban Planning 68(2-3):305-319. https://doi.org/10.1016/S0169-2046 (03)00163-4

Jongman, R. H., and G. Pungetti. 2004. Ecological networks and greenways: concept, design, implementation. Cambridge University Press, Cambridge, UK. https://doi.org/10.1017/ $\underline{\mathrm{CBO} 9780511606762}$

Kahn, P. H. 2002. Children's affiliations with nature: structure, development, and the problem of environmental generational amnesia. Pages 93-116 in P. H. Kahn, Jr. and S. R. Kellert, editors. Children and nature: psychological, sociocultural, and evolutionary investigations. MIT Press, Cambridge, Massachusetts, USA. https://doi.org/10.7551/mitpress/1807.003.0005

Khalsa, S. B. S., M. E. Jewett, C. Cajochen, and C. A. Czeisler. 2003. A phase response curve to single bright light pulses in human subjects. Journal of Physiology 549(3):945-952. https:// doi.org/10.1113/jphysiol.2003.040477

Knop, E., L. Zoller, R. Ryser, C. Gerpe, M. Hörler, and C. Fontaine. 2017. Artificial light at night as a new threat to pollination. Nature 548(7666):206-209. https://doi.org/10.1038/ nature23288

Koslofsky, C. 2011. Evening's empire: a history of the night in early modern Europe. Cambridge University Press, Cambridge, UK.

Kyba, C. C., T. Kuester, A. S. de Miguel, K. Baugh, A. Jechow, F. Hölker, J. Bennie, C. D. Elvidge, K. J. Gaston, and L. Guanter. 2017. Artificially lit surface of Earth at night increasing in radiance and extent. Science Advances 3(11):e1701528. https:// doi.org/10.1126/sciadv.1701528

Kyba, C. C., A. Ruby, H. U. Kuechly, B. Kinzey, N. Miller, J. Sanders, J. Barentine, R. Kleinodt, and B. Espey. 2020. Direct measurement of the contribution of street lighting to satellite observations of nighttime light emissions from urban areas. Lighting Research \& Technology. https://doi.org/10.1177/1477153520958463

Laforge, A., J. Pauwels, B. Faure, Y. Bas, C. Kerbiriou, J. Fonderflick, and A. Besnard. 2019. Reducing light pollution improves connectivity for bats in urban landscapes. Landscape Ecology 34(4):793-809. https://doi.org/10.1007/s10980-019-00803-0

Lam, Y. M. 2020. More than darkness preservation: the importance of the dark, star-filled skies in urban areas. Nature and Culture 15(3):296-317. https://doi.org/10.3167/nc.2020.150304

Lapostolle, D., and S. Challéat. 2021. Making darkness a placebased resource: how the fight against light pollution reconfigures rural areas in France. Annals of the American Association of Geographers 111(1):196-215. https://doi.org/10.1080/24694452.2$\underline{020.1747972}$
Lapostolle, D., S. Challéat, J. Milian, and P.-O. Dupuy. 2015. The appropriation of the energy transition for the protection of nighttime environmental resources: experiences from the Pyrenees and the Southern Alps. Géocarrefour 90(4):351-360. https://doi.org/10.4000/geocarrefour.9967

Latour, B. 2004. Politics of nature. Harvard University Press, Cambridge, Massachusetts, USA.

Le Gallic, S., and S. B. Pritchard. 2019. Light(s) and darkness(es): looking back, looking forward. Journal of Energy History/Revue d'Histoire de l'Énergie n ${ }^{\circ}$ 2. [online] URL: http://energyhistory.eu/ en/special-issue/lights-and-darknesses-looking-back-looking-forward

Leach, M., K. Raworth, and J. Rockström. 2013. Between social and planetary boundaries: navigating pathways in the safe and just space for humanity. Pages 84-89 in World social science report: changing global environments. OECD, Paris, France, UNESCO, Paris, France. https://doi.org/10.1787/9789264203419-10-en

Lee, K. N. 1993. Greed, scale mismatch and learning. Ecological Applications (3):560-564.

Lévêque, C. 2017. La biodiversité: avec ou sans l'homme? Réflexions d'un écologue sur la protection de la nature en France. Editions Quae, Versailles, France.

Levins, R. 1969. Some demographic and genetic consequences of environmental heterogeneity for biological control. American Entomologist 15(3):237-240. https://doi.org/10.1093/besa/15.3.237

Lewanzik, D., and C. C. Voigt. 2014. Artificial light puts ecosystem services of frugivorous bats at risk. Journal of Applied Ecology 51(2):388-394. https://doi.org/10.1111/1365-2664.12206

Lučan, R., and J. Radil. 2010. Variability of foraging and roosting activities in adult females of Daubenton's bat (Myotis daubentonii) in different seasons. Biologia 65(6):1072-1080. https://doi.org/10.2478/s11756-010-0124-5

Ludvigsen, M., J. Berge, M. Geoffroy, J. H. Cohen, P. R. De La Torre, S. M. Nornes, H. Singh, A. J. Sørensen, M. Daase, and G. Johnsen. 2018. Use of an autonomous surface vehicle reveals small-scale diel vertical migrations of zooplankton and susceptibility to light pollution under low solar irradiance. Science Advances 4(1):eaap9887. https://doi.org/10.1126/sciadv.aap9887

MacArthur, R. H., and E. O. Wilson. 1967. The theory of island biogeography. Princeton University Press, Princeton, New Jersey, USA. https://doi.org/10.1515/9781400881376

Manfrin, A., G. Singer, S. Larsen, N. Weiß, R. H. van Grunsven, N. S. Weiß, S. Wohlfahrt, M. T. Monaghan, and F. Hölker. 2017. Artificial light at night affects organism flux across ecosystem boundaries and drives community structure in the recipient ecosystem. Frontiers in Environmental Science 5:61. https://doi. org/10.3389/fenvs.2017.00061

Margules, C. R., and R. L. Pressey. 2000. Systematic conservation planning. Nature 405:243-253. https://doi.org/10.1038/35012251

Mascia, M. B., J. P. Brosius, T. A. Dobson, B. C. Forbes, L. Horowitz, M. A. McKean, and N. J. Turner. 2003. Conservation and the social sciences. Conservation Biology 17(3):649-650. https://doi.org/10.1046/j.1523-1739.2003.01738.x 
Mathevet, R. 2012. La solidaritéécologique. Ce lien quinous oblige. Actes Sud, Paris, France.

Mathevet, R., J. Thompson, O. Delanoë, M. Cheylan, C. GilFourrier, and M. Bonnin. 2010. La solidarité écologique: un nouveau concept pour une gestion intégrée des parcs nationaux et des territoires. Natures Sciences Sociétés 18:424-433. https:// doi.org/10.1051/nss/2011006

Mathevet, R., J. D. Thompson, C. Folke, and F. S. Chapin III. 2016. Protected areas and their surrounding territory: socioecological systems in the context of ecological solidarity. Ecological Applications 26(1):5-16. https://doi.org/10.1890/14-0421

McLaren, J. D., J. J. Buler, T. Schreckengost, J. A. Smolinsky, M. Boone, E. E. van Loon, D. K. Dawson, and E. L. Walters. 2018. Artificial light at night confounds broad-scale habitat use by migrating birds. Ecology Letters 21(3):356-364. https://doi. org/10.1111/ele.12902

McShane, T. O., and M. P. Wells. 2004. Integrated conservation and development. Pages 3-9 in T. O. McShane and M. P. Wells, editors. Getting biodiversity projects to work: towards more effective conservation and development. Columbia University Press, New York, New York, USA. https://doi.org/10.7312/mcsh12764-003

Miller, J. R. 2005. Biodiversity conservation and the extinction of experience. Trends in Ecology \& Evolution 20(8):430-434. https:// doi.org/10.1016/j.tree.2005.05.013

Miller, J. R. 2006. Restoration, reconciliation, and reconnecting with nature nearby. Biological Conservation 127(3):356-361. https://doi.org/10.1016/j.biocon.2005.07.021

Mitchell, D., and T. Gallaway. 2019. Dark sky tourism: economic impacts on the Colorado Plateau Economy, USA. Tourism Review 74(4):930-942. https://doi.org/10.1108/TR-10-2018-0146

Najjar, R. P., C. Chiquet, P. Teikari, P.-L. Cornut, B. Claustrat, P. Denis, H. M. Cooper, and C. Gronfier. 2014. Aging of nonvisual spectral sensitivity to light in humans: compensatory mechanisms? PLoS ONE 9(1):e85837. https://doi.org/10.1371/ journal.pone. 0085837

Najjar, R. P., and J. M. Zeitzer. 2016. Temporal integration of light flashes by the human circadian system. Journal of Clinical Investigation 126(3):938-947. https://doi.org/10.1172/JCI82306

Newson, S. E., H. E. Evans, and S. Gillings. 2015. A novel citizen science approach for large-scale standardised monitoring of bat activity and distribution, evaluated in eastern England. Biological Conservation 191:38-49. https://doi.org/10.1016/j.biocon.2015.06.009

Olivier de Sardan, J. P. O. 1988. Jeu de la croyance et "je" ethnologique: exotisme religieux et ethno-égo-centrisme. Cahiers d'Études Africaines 28(111/112):527-540 https://doi.org/10.3406/ cea.1988.1665

Opdam, P., E. Steingröver, and S. Van Rooij. 2006. Ecological networks: a spatial concept for multi-actor planning of sustainable landscapes. Landscape and Urban Planning 75 (3-4):322-332. https://doi.org/10.1016/j.landurbplan.2005.02.015

Painter, K. 1996. The influence of street lighting improvements on crime, fear and pedestrian street use, after dark. Landscape and Urban Planning 35(2-3):193-201. https://doi.org/10.1016/0169-2046 (96)00311-8

Pauwels, J., I. Le Viol, C. Azam, N. Valet, J.-F. Julien, Y. Bas, C. Lemarchand, A. Sanchez de Miguel, and C. Kerbiriou. 2019. Accounting for artificial light impact on bat activity for a biodiversity-friendly urban planning. Landscape and Urban Planning 183:12-25. https://doi.org/10.1016/j.landurbplan.2018.08.030

Perkin, E. K., F. Hölker, and K. Tockner. 2014. The effects of artificial lighting on adult aquatic and terrestrial insects. Freshwater Biology 59(2):368-377. https://doi.org/10.1111/ fwb. 12270

Pinaud, D., F. Claireau, M. Leuchtmann, and C. Kerbiriou. 2018. Modelling landscape connectivity for greater horseshoe bat using an empirical quantification of resistance. Journal of Applied Ecology 55(6):2600-2611. https://doi.org/10.1111/1365-2664.13228

Prayag, A. S., R. P. Najjar, and C. Gronfier. 2019. Melatonin suppression is exquisitely sensitive to light and primarily driven by melanopsin in humans. Journal of Pineal Research 66(4): e12562. https://doi.org/10.1111/jpi.12562

Prévot, A.-C., V. Servais, and A. Piron. 2016. Scientist and nonscientists share a diversity of dimensions in their relations to urban nature. Urban Ecosystems 19(4):1787-1799. https://doi. org/10.1007/s11252-016-0565-X

Pyle, R. M. 1978. The extinction of experience. Horticulture (56):64-67.

Raffestin, C. 1988. Le territoire, la territorialité et la nuit. Actualités psychiatriques 2:48-50. [online] URL: https://archiveouverte.unige.ch/unige:4358/ATTACHMENT01

Reed, M. S. 2008. Stakeholder participation for environmental management: a literature review. Biological Conservation 141 (10):2417-2431. https://doi.org/10.1016/j.biocon.2008.07.014

Rich, C., and T. Longcore. 2006. Ecological consequences of artificial night lighting. Island, Washington, D.C., USA.

Riegel, K. W. 1973. Light pollution: outdoor lighting is a growing threat to astronomy. Science 179(4080):1285-1291. https://doi. org/10.1126/science.179.4080.1285

Rientjes, S., and K. Roumelioti. 2003. Support for ecological networks in European nature conservation: an indicative socialmap. ECNC Technical report series. European Centre for Nature Conservation, Tilburg, The Netherlands. [online] URL: $\underline{\text { https:// }}$ www.cipra.org/en/publications/3813

Rimmer, D. W., D. B. Boivin, T. L. Shanahan, R. E. Kronauer, J. F. Duffy, and C. A. Czeisler. 2000. Dynamic resetting of the human circadian pacemaker by intermittent bright light. American Journal of Physiology-Regulatory, Integrative and Comparative Physiology 279(5):R1574-R1579. https://doi. org/10.1152/ajpregu.2000.279.5.R1574

Rodríguez, A., P. Dann, and A. Chiaradia. 2017. Reducing lightinduced mortality of seabirds: high pressure sodium lights decrease the fatal attraction of shearwaters. Journal for Nature Conservation 39:68-72. https://doi.org/10.1016/j.jnc.2017.07.001 
Rodrigues, A. L., A. Rodrigues, and D. M. Peroff. 2015. The sky and sustainable tourism development: a case study of a dark sky reserve implementation in Alqueva. International Journal of Tourism Research 17(3):292-302. https://doi.org/10.1002/jtr.1987

Roger, A. 1997. Court traité du paysage. Gallimard, Paris, France.

Rydell, J. 1992. Exploitation of insects around streetlamps by bats in Sweden. Functional Ecology 6(6):744-750. https://doi. org/10.2307/2389972

Salvarina, I., D. Gravier, and K.-O. Rothhaupt. 2018. Seasonal bat activity related to insect emergence at three temperate lakes. Ecology and Evolution 8(7):3738-3750. https://doi.org/10.1002/ $\underline{\text { ece } 3.3943}$

Samways, M. J., and J. S. Pryke. 2016. Large-scale ecological networks do work in an ecologically complex biodiversity hotspot. Ambio 45(2):161-172. https://doi.org/10.1007/s13280-015-0697$\underline{x}$

Sanders, D., E. Frago, R. Kehoe, C. Patterson, and K. J. Gaston. 2021. A meta-analysis of biological impacts of artificial light at night. Nature Ecology \& Evolution 5:74-81. https://doi. org/10.1038/s41559-020-01322-X

Schaller, M., J. Park, and J. Faulkner. 2003. Prehistoric dangers and contemporary prejudices. European Review of Social Psychology 14(1):105-137. https://doi.org/10.1080/10463280340000036

Schroer, S., and F. Hölker. 2017. Impact of lighting on flora and fauna. Pages 1-33 in R. Karlicek, C.-C. Sun, G. Zissis, R. Ma, editors. Handbook of advanced lighting technology. Springer, Cham, Switzerland. https://doi.org/10.1007/978-3-319-00295-8_42-1

Schroer, S., B. J. Huggins, C. Azam, and F. Hölker. 2020. Working with inadequate tools: legislative shortcomings in protection against ecological effects of artificial light at night. Sustainability 12(6):2551. https://doi.org/10.3390/su12062551

Sébastien, L. 2020. The power of place in understanding place attachments and meanings. Geoforum 108:204-216. https://doi. org/10.1016/j.geoforum.2019.11.001

Secondi, J., V. Dupont, A. Davranche, N. Mondy, T. Lengagne, and M. Théry. 2017. Variability of surface and underwater nocturnal spectral irradiance with the presence of clouds in urban and peri-urban wetlands. PLoS ONE 12(11):e0186808. https:// doi.org/10.1371/journal.pone.0186808

Shafer, C. L. 1999a. U.S. national park buffer zones: historical, scientific, social, and legal aspects. Environmental Management 23(1):49-73. https://doi.org/10.1007/s002679900167

Shafer, C. L. 1999b. National park and reserve planning to protect biological diversity: some basic elements. Landscape and Urban Planning 44(2-3):123-153. https://doi.org/10.1016/s0169-2046 (98)00115-7

Shaw, R. 2018. The nocturnal city. Routledge, London, UK. https://doi.org/10.4324/9781315560090

Silver, D. A., and G. M. Hickey. 2020. Managing light pollution through dark sky areas: learning from the world's first dark sky preserve. Journal of Environmental Planning and Management 63 (14):2627-2645. https://doi.org/10.1080/09640568.2020.1742675
Skandrani, Z., and A.-C. Prévot. 2015. Beyond green-planning political orientations: contrasted public policies and their relevance to nature perceptions in two European capitals. Environmental Science \& Policy (52):140-149. https://doi. org/10.1016/j.envsci.2015.04.015

Soga, M., and K. J. Gaston. 2016. Extinction of experience: the loss of human-nature interactions. Frontiers in Ecology and the Environment 14(2):94-101. https://doi.org/10.1002/fee.1225

Soulé, M. E., and G. Orians. 2001. Conservation biology: research priorities for the next decade. Island, Washington, D.C., USA.

Spoelstra, K., R. H. A. van Grunsven, J. J. C. Ramakers, K. B. Ferguson, T. Raap, M. Donners, E. M. Veenendaal, and M. E. Visser. 2017. Response of bats to light with different spectra: lightshy and agile bat presence is affected by white and green, but not red light. Proceedings of the Royal Society B: Biological Sciences 284(1855):20170075. https://doi.org/10.1098/rspb.2017.0075

Stone, E. L., S. Harris, and G. Jones. 2015. Impacts of artificial lighting on bats: a review of challenges and solutions. Mammalian Biology 80(3):213-219. https://doi.org/10.1016/j.mambio.2015.02.004

Stone, E. L., G. Jones, and S. Harris. 2009. Street lighting disturbs commuting bats. Current Biology 19(13):1123-1127. https://doi. org/10.1016/j.cub.2009.05.058

Stone, T. 2017. The value of darkness: a moral framework for urban nighttime lighting. Science and Engineering Ethics 24:607-628. https://doi.org/10.1007/s11948-017-9924-0

Tengö, M., E. S. Brondizio, T. Elmqvist, P. Malmer, and M. Spierenburg. 2014. Connecting diverse knowledge systems for enhanced ecosystem governance: the multiple evidence base approach. Ambio 43(5):579-591. https://doi.org/10.1007/s13280-014-0501-3

Tengö, M., R. Hill, P. Malmer, C. M. Raymond, M. Spierenburg, F. Danielsen, T. Elmqvist, and C. Folke. 2017. Weaving knowledge systems in IPBES, CBD and beyond-lessons learned for sustainability. Current Opinion in Environmental Sustainability 26-27:17-25. https://doi.org/10.1016/j.cosust.2016.12.005

Termeer, C. J. A. M., A. Dewulf, and M. van Lieshout. 2010. Disentangling scale approaches in governance research: comparing monocentric, multilevel, and adaptive governance. Ecology and Society 15(4):29. https://doi.org/10.5751/ES-03798-150429

Thapan, K., J. Arendt, and D. J. Skene. 2001. An action spectrum for melatonin suppression: evidence for a novel non-rod, noncone photoreceptor system in humans. Journal of Physiology 535 (1):261-267. https://doi.org/10.1111/j.1469-7793.2001.t01-1-00261. $\underline{\mathrm{X}}$

Thompson, J. D., R. Mathevet, O. Delanoë, C. Gil-Fourrier, M. Bonnin, and M. Cheylan. 2011. Ecological solidarity as a conceptual tool for rethinking ecological and social interdependence in conservation policy for protected areas and their surrounding landscape. Comptes rendus biologies 334 (5-6):412-419. https://doi.org/10.1016/j.crvi.2011.02.001

Touzot, M., L. Teulier, T. Lengagne, J. Secondi, M. Théry, P.-A. Libourel, L. Guillard, and N. Mond. 2020. Artificial light at night disturbs the activity and energy allocation of the common toad 
during the breeding period. Conservation Physiology 7(1):coz002. https://doi.org/10.1093/conphys/coz002

United Nations Environment Programme (UNEP). 2012. The rapid transition to energy efficient lighting: an integrated policy approach. UNEP, Global Environment Facility. [online] URL: https:/europa.eu/capacity4dev/file/14168/download?token=fFhB RQR

United Nations Environment Programme (UNEP). 2017. Accelerating the global adoption of energy-efficient lighting. UNEP, Global Environment Facility | United for Efficiency (U4E), Paris, France. [online] URL: https://wedocs.unep.org/ bitstream/handle/20.500.11822/20406/Energy efficient lighting.pdf? sequence $=1 \&$ is Allowed $=\mathrm{y}$

Van Doren, B. M., K. G. Horton, A. M. Dokter, H. Klinck, S. B. Elbin, and A. Farnsworth. 2017. High-intensity urban light installation dramatically alters nocturnal bird migration. Proceedings of the National Academy of Sciences 114 (42):11175-11180. https://doi.org/10.1073/pnas.1708574114

van Grunsven, R. H. A., J. Becker, S. Peter, S. Heller, and F. Hölker. 2019. Long-term comparison of attraction of flying insects to streetlights after the transition from traditional light sources to light-emitting diodes in urban and peri-urban settings. Sustainability 11(22):6198. https://doi.org/10.3390/su11226198

van Grunsven, R. H. A., R. Creemers, K. Joosten, M. Donners, and E. M. Veenendaal. 2017. Behaviour of migrating toads under artificial lights differs from other phases of their life cycle. Amphibia-Reptilia 38(1):49-55. https://doi.org/10.1163/15685381-00003081

van Langevelde, F., J. A. Ettema, M. Donners, M. F. WallisDeVries, and D. Groenendijk. 2011. Effect of spectral composition of artificial light on the attraction of moths. Biological Conservation 144(9):2274-2281. https://doi.org/10.1016/ j.biocon.2011.06.004

Vimal, R., and R. Mathevet. 2011. La carte et le territoire: le réseau écologique à l'épreuve de l'assemblée cartographique. Cybergeo: European Journal of Geography [online] URL: http:// journals.openedition.org/cybergeo/24841 https://doi.org/10.4000/ cybergeo. 24841

Vimal, R., R. Mathevet, and J. D. Thompson. 2012. The changing landscape of ecological networks. Journal for Nature Conservation 20(1):49-55. https://doi.org/10.1016/j.jnc.2011.08.001

Voigt, C. C., C. Azam, J. Dekker, J. Ferguson, M. Fritze, S. Gazaryan, F. Hölker, G. Jones, N. Leader, D. Lewanzik, H. J. G. A. Limpens, F. Mathews, J. Rydell, H. Schofield, K. Spoelstra, and M. Zagmajster. 2018. Guidelines for consideration of bats in lighting projects. EUROBATS Publication Series No. 8. UNEP/ EUROBATS Secretariat, Bonn, Germany.

Welbers, A. A. M. H., N. E. van Dis, A. M. Kolvoort, J. Ouyang, M. E. Visser, K. Spoelstra, and D. M. Dominoni. 2017. Artificial light at night reduces daily energy expenditure in breeding great tits (Parus major). Frontiers in Ecology and Evolution 5(55). https:// doi.org/10.3389/fevo.2017.00055

Witherington, B. E., and K. A. Bjorndal. 1991. Influences of artificial lighting on the seaward orientation of hatchling loggerhead turtles Caretta caretta. Biological Conservation 55 (2):139-149. https://doi.org/10.1016/0006-3207(91)90053-C

Zask, J. 2011. Participer. Essai sur les formes démocratiques de la participation. Les Éditions du Bord de l'eau, Lormont, France.

Zeale, M. R. K., E. L. Stone, E. Zeale, W. J. Browne, S. Harris, and G. Jones. 2018. Experimentally manipulating light spectra reveals the importance of dark corridors for commuting bats. Global Change Biology 24:5909-5918. https://doi.org/10.1111/ gcb. 14462

Zeitzer, J. M., S. B. S. Khalsa, D. B. Boivin, J. F. Duffy, T. L. Shanahan, R. E. Kronauer, and C. A. Czeisler. 2005. Temporal dynamics of late-night photic stimulation of the human circadian timing system. American Journal of Physiology-Regulatory, Integrative and Comparative Physiology 289(3):R839-R844. https://doi.org/10.1152/ajpregu.00232.2005 